Creative Commons User License: CC BY-NC-ND

Abstracted by: EBSCOhost, Electronic Journals Service (EJS),

Google Scholar, Journal Seek, Scientific Commons,

Food and Agricultural Organization (FAO), CABI and Scopus
Journal of Agricultural Extension

Vol. 23 (4) October, 2019

ISSN(e): 24086851; ISSN(Print); 1119944X

http://journal.aesonnigeria.org

http://www.ajol.info/index.php/iae

Email: editorinchief@aesonnigeria.org

\title{
Differences in Entrepreneurial Diversification among Male and Female Rural Farming Household in Kwara State, Nigeria \\ https://dx.doi.org/10.4314/jae.v23i4.18
}

\section{Daudu, Abdulrazaq Kamal}

Department of Agricultural Extension and Rural Development,

University of Ilorin, Ilorin, Nigeria

Corresponding author: daudu.ak@unilorin.edu.ng +23408032853580

\section{Oladipo, Felix Olayinka}

Department of Agricultural Extension and Rural Development, University of Ilorin, Ilorin, Nigeria

Email: felixoladipo5@gmail.com, +2348032275101

\section{Olatinwo, Latifat Kehinde}

Department of Agricultural Economics \& Extension,

Kwara State University, Malete, Nigeria

Email: latifatolatinwo@hotmail.com, +2348063134705

\section{Kareem, Oyedola Waheed}

Department of Agricultural Extension and Rural Development, University of Ilorin, Ilorin, Nigeria

Email: kareem.ow@unilorin.edu.ng, +2348032151063

\section{Dolapo, Tawakalitu Abiola}

Department of Agricultural Extension and Rural Development, University of Ilorin, Ilorin, Nigeria

Email: dolapo.ta@unilorin.edu.ng, +2348060161228

\section{Isiaka, Rilan Abayomi}

Department of Agricultural Extension and Rural Development, University of Ilorin, Ilorin, Nigeria

Email: isiaka.abayomi@yahoo.com, +2348091135274

\section{Abstract}

The study examined differences in entrepreneurial diversification among male and female rural farming household in Kwara State, Nigeria. A two-stage sampling procedure was used to select a total sample size of 320 respondents. Percentages, mean and regression were used for data analysis. Findings revealed that male and female farmers engaged in several entrepreneurial activities but men (0.51) were more diversified than female (0.47). Level of education, household size and access to credit were the major determinants of the entrepreneurial creativity of the respondents varying degree of significance. Both men and women were differentiated along entrepreneurial activities in search of daily need but men were more creative compared to their women counterparts. Education of male and female entrepreneurs should be encouraged and access to resources among rural farming households to stem up their creative thinking.

Keywords: Entrepreneurial creativity, rural farming household 
Creative Commons User License: CC BY-NC-ND

Abstracted by: EBSCOhost, Electronic Journals Service (EJS), Google Scholar, Journal Seek, Scientific Commons,

Food and Agricultural Organization (FAO), CABI and Scopus
Journal of Agricultural Extension

Vol. 23 (4) October, 2019

ISSN(e): 24086851; ISSN(Print); 1119944X

http://journal.aesonnigeria.org

http://www.ajol.info/index.php/jae

Email: editorinchief@aesonnigeria.org

\section{Introduction}

One of the important strategies of sustainable economic development is the promotion of entrepreneurial activities in sub-Saharan Africa. Entrepreneurship is generally described as the ability of an individual or a group of individuals to create or discover an opportunity and utilize it to the benefit of the society, which, in turn, will bring success to the innovators and their organization. According to Dau and Cuervo-Cazurra (2014), define entrepreneurship as the creation of fresh businesses a stable collection of people who coordinate their efforts to produce fresh valueadded economic activity'. Entrepreneurship remains the gateway to sustainable wealth creation in Nigeria (Ogundele, Akingbade and Akinlabi, 2012; Nkpoyen and Bassey, 2012; Nwala, 2013; Idris, 2015). Entrepreneurial creativity is needed by every entrepreneur to identify and grasp opportunity, to sustain competition and maintain competitive advantage in his/her business. The ability to turn creativity into a marketable product is expected of an entrepreneur. Being innovative is what is needed. Innovation means "to renew or change or start something new for the first time". Thus, the life of these rural-small- scale farmers have improved as a result of applying strategic entrepreneurship skills in the farming business.

Sex disparities in access to economic opportunities among the rural entrepreneurs are frequently debated in academic discuss in relation to sex compositions and participation in entrepreneurial activities. As compared to men, there are a slight lower number of women worldwide engaged in entrepreneurial activity. According to Global Entrepreneurship Monitor (GEM, 2012) more than 187 million women are engaged in entrepreneurial activity. Globally, the gender gap does not seem to be that alarming. The author further shows that men make up $52 \%$ of all entrepreneurial activity compared to $48 \%$ of women entrepreneurs. However, sex gap varies greatly in size across the globe but ranges from $1.5 \%$ to $45.4 \%$ women of the adult population who actively operate a venture as entrepreneurs or who are thinking about starting or creating new business (GEM, 2012). In sub-Saharan Africa, (Nigeria inclusive) the rate of men and women engaged in creating a new business vary and the only economy in sub-Saharan Africa with currently more female than male entrepreneurs is Ghana where about $55 \%$ of entrepreneurial activity is carried out by women (GEM, 2012).

Women make up close to or more than half of entrepreneurs in sub Saharan Africa. Using GDP per capita, the sex disparities in entrepreneurship is most visible in the middle income and transitional countries where men are $75 \%$ more likely than women to set up or start a new business but in countries with huge income, the sex gap is marginally small and men are $33 \%$ more likely to go into new venture or start a business whereas in developing countries it is 41\% (UNDP, 2013). However, a multi-year analysis (GEM, 2012) shows that even though the sex gap has persisted across most economies, changes are occurring and the gap, at least measured in terms of male to female ratio, may be closing. The disparities become more apparent though when women's motives to create or venture into a new business are compared to that of men. Worldwide, women are much more likely to be driven by necessity than men when creating a new business. This is because a growing 
Creative Commons User License: CC BY-NC-ND

Abstracted by: EBSCOhost, Electronic Journals Service (EJS), Google Scholar, Journal Seek, Scientific Commons,

Food and Agricultural Organization (FAO), CABI and Scopus
Journal of Agricultural Extension

Vol. 23 (4) October, 2019

ISSN(e): 24086851; ISSN(Print); 1119944X

http://journal.aesonnigeria.org

http://www.ajol.info/index.php/jae

Email: editorinchief@aesonnigeria.org

amount of research shows that countries that fail to address sex barriers are losing out on significant economic growth.

In most third world countries, the majority of women are involved in entrepreneurial activity driven by pure survival - out of necessity rather than opportunity - because there are no jobs or any other options for income generation to improve their livelihood. This partly explains why globally women are overrepresented in the informal economy and own not more than $25 \%$ of formal sector businesses, and stands in contrast to the vast majority of women in high-income countries, where $2 / 3$ of women start a business because they see opportunities or want to be independent. However, the sex gap in entrepreneurship measured by motive may gradually disappear as recent data demonstrate that as economies develop and grow, and job opportunities become available, this gap may be closing with time the proportion of women with necessity motivations declined in recent years, especially in developed countries thereby contributing to a narrowing of the gender gap (GEM, 2012).

Previous gender studies in Nigeria on entrepreneurship creativity focused more on the traits and characteristics. Nwibo and Okorie (2013) examined the constraints to entrepreneurship among investors in southeast Nigeria. A wide variety of research has examined performance differences between women and men entrepreneurs in rural farm setting. While many studies find significant differences between men and women with regards to income and productivity, explanations for these differences vary widely. This is problematic, as we believe that the real reason for differences stems from the difference in entrepreneurial creativity between women and men entrepreneurs.

\section{Purpose of study}

The overall purpose of the study was to examine the differences in entrepreneurial creativity among men and women in rural farming household of Kwara State, Nigeria. Specifically, the study:

i. identified various entrepreneurial diversification engaged in by male and female rural farmers; and

ii. determined factors influencing entrepreneurial creativity among male and female rural farmers.

\section{Methodology}

The study was conducted in Kwara State, Nigeria. It is located between latitude $8^{\circ} 5^{1}$ $-10^{\circ} 4^{\prime} \mathrm{N}$ and longitude $4^{\circ} 55^{\prime}-6^{\circ} 5^{\prime} \mathrm{E}$ covering an estimated land area of 32,500 $\mathrm{km}$ with a projected population of about 3.2 million (National Population Commission, 2016). Multistage sampling technique was used in the selection of respondents. First stage, involved a random selection of eight (8) Local Government areas (LGA) from sixteen LGAs (i.e. two LGAs from each of the four (4) Agricultural Development Programme zones) in the state. Second stage was a random selection of two (2) rural communities from each of the selected eight (8) LGA across the state making sixteen (16) rural communities. At the third stage, 20 farmers (10 male farmers and 10 female farmers) were randomly selected from each of the rural 
Creative Commons User License: CC BY-NC-ND

Abstracted by: EBSCOhost, Electronic Journals Service (EJS), Google Scholar, Journal Seek, Scientific Commons,

Food and Agricultural Organization (FAO), CABI and Scopus
Journal of Agricultural Extension

Vol. 23 (4) October, 2019

ISSN(e): 24086851; ISSN(Print); 1119944X

http://journal.aesonnigeria.org

http://www.ajol.info/index.php/iae

Email: editorinchief@aesonnigeria.org

communities used for the study. A total of 320 respondents (154 male farmers and 166 female farmers) participated in the study. Data were collected with interview and analysed using frequency counts, charts, means and standard deviation, percentages and regression. The Simpson's Diversity Index was used to measure the diversity of entrepreneurial activities engaged into by male and female farmers in the study area.

The Diversity Index is expressed as:

$D I=1-\sum_{i=0}^{s}\left(\frac{n}{N}\right)^{2}$

Where $N=\sum n_{i}=$ Total population of all individuals across all entrepreneurial activities

$\mathrm{S}=$ Number of entrepreneurial activities engaged into by male and female farmers

$n_{i}$ (for $i=1$ to $s$ ) is the number of individuals in the ith entrepreneurial activity

Binary logistic regression model was used to estimate factors influencing the entrepreneurial creativity among two categories (male and female) of rural farmers. The binary logistic regression model is in the form of the ratio of natural logarithm of the probability (i.e. log odds ratio), which can be expressed as follows;

$$
\boldsymbol{Y} \boldsymbol{i}=\beta_{0}+\beta X^{s i}+\mu \boldsymbol{i}
$$

Where $\boldsymbol{Y}_{i}=$ Conditional probability of a category of farmer's creativity,

$\boldsymbol{X}_{i}=$ A matrix of independent variables such as age, educational level, household

size, access to credit, contact with extension agent

$\boldsymbol{\beta}_{0}=$ Constant and vector of unknown parameters to be estimated

$\boldsymbol{\beta}_{i}=$ Coefficient of independent variable(s)

$\boldsymbol{\mu}_{i}=$ Random error term

\section{Results and Discussion}

\section{Entrepreneurial Activities Created by Male and Female Respondents}

Figure 1 reveals that there were about fifteen (15) entrepreneurial activities created by both male and female respondents. Among them, male involve more in crop activities $(26.1 \%)$ with few (18.4\%) of female involve in farming activities. This implies that many of the respondents (male and female) engaged in non-farming entrepreneurial activities in addition to farming. Also, $9.5 \%$ and $13.3 \%$ of male and female respondents engaged in livestock production, $5.7 \%$ and $22.4 \%$ of male and female engaged in agro-processing activities and 9.2 and $19.6 \%$ of male and female diversify into marketing of farm produce. This finding suggests that female respondents created or engaged more in non-farm entrepreneurial activities than their male counterparts. This indicates that the majority of the female respondents 
Creative Commons User License: CC BY-NC-ND

Abstracted by: EBSCOhost, Electronic Journals Service (EJS), Google Scholar, Journal Seek, Scientific Commons,

Food and Agricultural Organization (FAO), CABI and Scopus
Journal of Agricultural Extension

Vol. 23 (4) October, 2019

ISSN(e): 24086851; ISSN(Print); 1119944X

http://journal.aesonnigeria.org

http://www.ajol.info/index.php/iae

Email: editorinchief@aesonnigeria.org

are pluriactive. This is because the women play a vital role in household poverty reduction couple with assistance from family and relatives. Thus, by removing the financial barrier in the ecosystem for women, they tend to create more innovative new ventures than males that perceive less supportive by family members. Empowered women who make decisions about planting materials and inputs have been found to be more productive in agricultural activities than men (Quisumbing et al.2014).

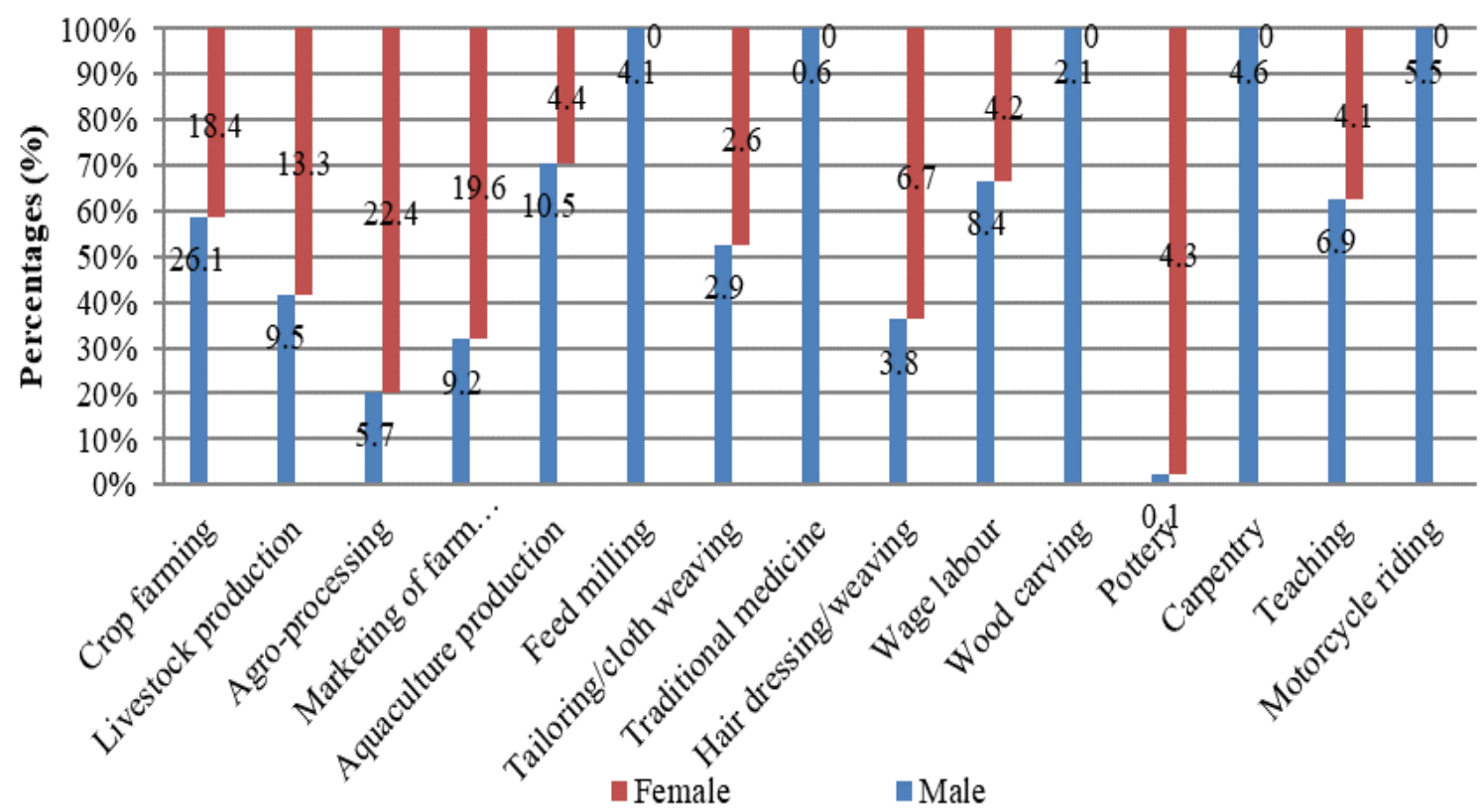

Figure 1: Entrepreneurial activities created by male and female farmers Source: Field survey, 2017

\section{Reasons for Engaging in Entrepreneurial Activities}

Figure 2 shows that $28 \%$ of the male respondents involved in entrepreneurial activities to have adequate food security for their family, $40 \%$ to increase their income generation, $14 \%$ involved in entrepreneurial activities to improved their livelihood while $10 \%$ and $8 \%$ of male respondents were to be self sufficient and change their social status respectively. Also, among the female respondents most $(42 \%)$ involved in entrepreneurial activities to generate more income, $21 \%$ were to ensure adequate food for their family and $4 \%$ were to improved their standard of living while 9 and $25 \%$ of the female respondents involved various entrepreneurial activities to be self sufficient and improve their social status respectively. This finding aligned with that of Campaña, Giménez-Nadal and Molina (2017) that among the reasons for the focus on entrepreneurship in developing economies are: the promotion of growth through entrepreneurship, the effects on household welfare, and the reduction of poverty. 
Male
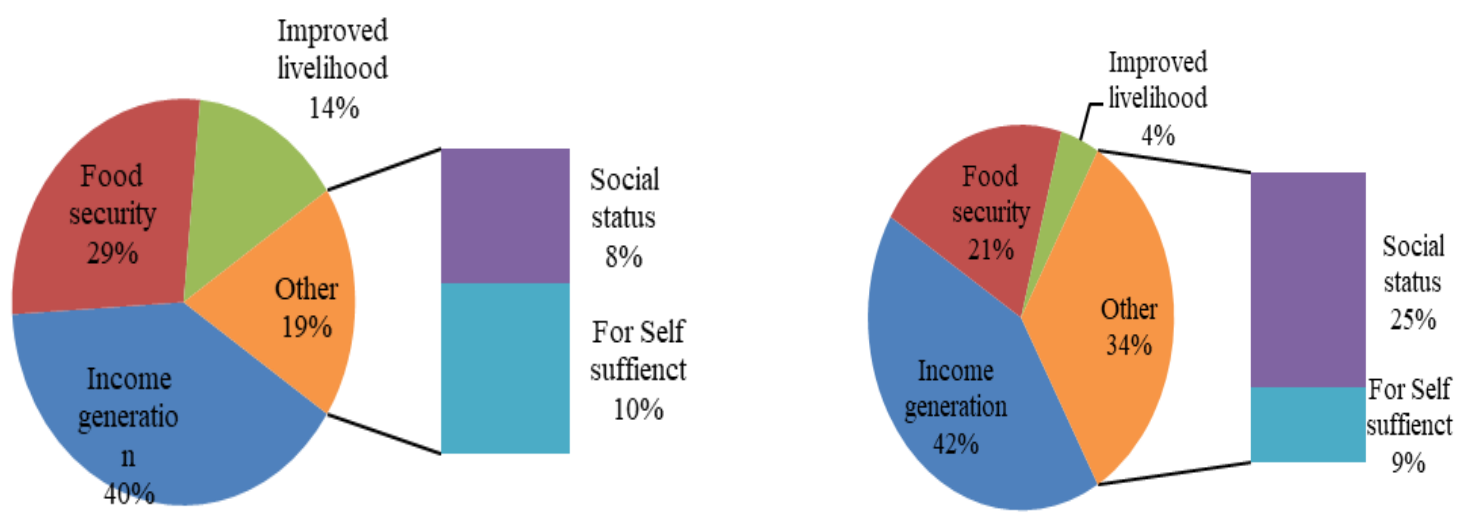

Figure 2: Reasons for engaging in entrepreneurial activities

Source: Field survey, 2017

\section{Diversity Index of Male and Female Farmers}

Table 1 shows that the male category indicated that crop farming (0.51), aquaculture (0.38) and livestock production (0.34) have higher ratios than most of other entrepreneurial activities they engaged in. This finding suggests that as the diversity index of farmers' increases, the diversity of entrepreneurial activities also increases. The implication is that the diversity of activities in the study area increases as the number of activities in the study area increases. Similarly, the female category indicated that marketing of farm produce with diversity index $(0.47)$, agro-processing (0.41) and tailoring/cloth weaving (0.36) and are considered as most diversified entrepreneurial activities among them. It can be inferred that male farmers diversified more than their female counterparts in most of entrepreneurial activities. This could be due to the fact that males have more responsibilities to attend to, compare to their female entrepreneurs. Women in many rural communities engage in petty trading and other income earning activities to supplement household income. Thus, women tend to be engaged in multiple entrepreneurial activities to supplement household income compared to men and play multiple roles in the household. The result of this study is consistent with that of Sadiya and Man (2012) which reported higher participation of women in entrepreneurial work in Malaysia. 
Creative Commons User License: CC BY-NC-ND

Abstracted by: EBSCOhost, Electronic Journals Service (EJS),

Google Scholar, Journal Seek, Scientific Commons,

Food and Agricultural Organization (FAO), CABI and Scopus
Journal of Agricultural Extension

Vol. 23 (4) October, 2019

ISSN(e): 24086851; ISSN(Print); 1119944X

http://journal.aesonnigeria.org

http://www.ajol.info/index.php/iae

Email: editorinchief@aesonnigeria.org

Table 1: Diversity index of male and female farmers

\begin{tabular}{lcccccc}
\hline $\begin{array}{c}\text { Entrepreneurial } \\
\text { activities created by } \\
\text { respondents }\end{array}$ & \multicolumn{2}{c}{ Ratio } & Rating & $\begin{array}{c}\text { Entrepreneurial } \\
\text { activities created by } \\
\text { respondents }\end{array}$ & \multicolumn{2}{c}{ Female } \\
Ratio & Rating \\
Crop farming & 0.51 & $1^{\text {st }}$ & Marketing of farm produce & 0.47 & $1^{\text {st }}$ \\
Aquaculture production & 0.38 & $2^{\text {nd }}$ & Agro-processing & 0.41 & $2^{\text {th }}$ \\
Livestock production & 0.34 & $3^{\text {rd }}$ & Tailoring/cloth weaving & 0.36 & $3^{\text {rd }}$ \\
Marketing of farm produce & 0.29 & $4^{\text {th }}$ & Crop farming & 0.28 & $4^{\text {th }}$ \\
Agro-processing & 0.26 & $5^{\text {th }}$ & Hair dressing/weaving & 0.25 & $5^{\text {th }}$ \\
Motorcycle riding & 0.24 & $6^{\text {th }}$ & Livestock production & 0.23 & $6^{\text {th }}$ \\
Tailoring/cloth weaving & 0.22 & $7^{\text {th }}$ & Pottery & 0.22 & $7^{\text {th }}$ \\
Wage labour & 0.21 & $8^{\text {th }}$ & Wage labour & 0.04 & $8^{\text {th }}$ \\
Hair dressing/weaving & 0.03 & $9^{\text {th }}$ & Aquaculture production & 0.03 & $9^{\text {th }}$ \\
Wood carving & 0.02 & $10^{\text {th }}$ & Teaching & 0.01 & $10^{\text {th }}$ \\
Teaching & 0.02 & $10^{\text {th }}$ & Carpentry & 0 & \\
Feed milling & 0.01 & $12^{\text {th }}$ & Feed milling & 0 & \\
Pottery & 0.01 & $12^{\text {th }}$ & Motorcycle riding & 0 & \\
Carpentry & 0.01 & $12^{\text {th }}$ & Wood carving & 0 &
\end{tabular}

Source: Field survey, 2017

\section{Factors Influencing Entrepreneurial Creativity of Male and Female Rural} Farmers

Table 2 shows that age was significant and negative for male farmers. It implies that a unit increase in age will have negative effect on their entrepreneurial creativity by $0.07 \%$. Experience is a function of age thus, increase in age may suggest an increase in experience and this suggests that the farmer may become more creative in entrepreneurial activities. On the other hand, female category indicated that age was not a significant factor determining their entrepreneurial creativity. The level of education was positive and significant for both male and female farmers. This suggests that the increase in the level of educational farmers will enhance their entrepreneurial creativity.Education strengthens the creative thinking and knowledge of human beings. Any increase in educational level of both male and female farmers will increase their entrepreneurial creativity by $0.36 \%$ and $2.68 \%$ for the male and female farmers each. Furthermore, Table 2 reveals that household size for both male and female rural farmers were positive and significant, implying that an increase in the household size of both male and female farmers will increase their level of entrepreneurial activities by $0.67 \%$ and $3.67 \%$ respectively. This suggests that large household would provide more labour for the entrepreneurial activities of the farmers especially for those that rely heavily on family labour. The male category indicated that the coefficient of contact with extension agents was positive; however, it was only significant at $10 \%$ in determining entrepreneurial creativity among the male farmers. This implies that, since most of the male farmers were mainly involved in farming activities, contact with extension agents is highly essential in transferring new yield increasing innovations to the farmers to increase household income and thus better their standard of living. In female category, extension contact was also positive but significant at $1 \%$ level of significance. This may be due to inadequate 
Creative Commons User License: CC BY-NC-ND

Abstracted by: EBSCOhost, Electronic Journals Service (EJS), Google Scholar, Journal Seek, Scientific Commons,

Food and Agricultural Organization (FAO), CABI and Scopus
Journal of Agricultural Extension

Vol. 23 (4) October, 2019

ISSN(e): 24086851; ISSN(Print); 1119944X

http://journal.aesonnigeria.org

http://www.ajol.info/index.php/iae

Email: editorinchief@aesonnigeria.org

number agricultural extension agents to relate and change the life of female farmers in the study area.

Access to credit facilities was positive and significant in determining the entrepreneurial activities engage in by the male and female farmers. This suggests that access to credit among male and female farmers will increase the probability that male or female farmers will engage in productive and profitable entrepreneurial activities and thereby raise their livelihood status. Having access to credit or loan facilities would enable both categories of entrepreneurs to expand their created business and since the bigger the business size the better the capacity to yield incentives for reinvestment, diversification and willingness on the part of entrepreneurs to initiate development efforts within the sector of his/her business operation. Farmers who had access to credit had a lower propensity to engage in more income generating activities, which is consistent with a priori expectation. This is because credit tends to ease the financial constraints of farm households and could increase on-farm income. Credit-constrained farmers are therefore more likely to seek employment from off-farm sources. The result of this study is contrary to Dzanku and Sarpong (2014) who found that access to credit enhanced female participation in entrepreneurial activities in Ghana.

\section{Table 2: Determinants of entrepreneurial creativity of rural farmers}

\begin{tabular}{|c|c|c|c|c|}
\hline \multirow{2}{*}{ Factors } & \multicolumn{2}{|c|}{ Male } & \multicolumn{2}{|c|}{ Female } \\
\hline & Coefficient & Standard Error & Coefficient & Standard Error \\
\hline Age & $-0.065^{\star *}$ & 0.541 & 0.159 & 0.167 \\
\hline Educational level & $0.363^{* * *}$ & 0.155 & $2.685^{\star *}$ & 0.652 \\
\hline Household size & 0.658 & 0.324 & $3.647^{* * *}$ & 0.455 \\
\hline Extension contact & 1.325 & 0.747 & 3.491 & 2.632 \\
\hline Access to credit & 1.267 & 0.708 & $0.258^{\star * *}$ & 0.046 \\
\hline Constant & 3.747 & 3.263 & 4.167 & 6.385 \\
\hline Log likelihood & \multicolumn{2}{|c|}{-12.6835} & \multicolumn{2}{|c|}{-19.291} \\
\hline Number of observation & \multicolumn{2}{|c|}{154} & \multicolumn{2}{|r|}{166} \\
\hline LR Chi2 (4) & \multicolumn{2}{|r|}{21.6} & \multicolumn{2}{|c|}{35.4} \\
\hline Prob>Chi2 & \multicolumn{2}{|c|}{0.005} & \multicolumn{2}{|c|}{0.002} \\
\hline Pseudo R2 & \multicolumn{2}{|c|}{0.3471} & \multicolumn{2}{|c|}{0.6902} \\
\hline
\end{tabular}

${ }^{* * *} \mathrm{P} \leq 0.01,{ }^{* *} \mathrm{P} \leq 0.05$. Source: Field survey, 2017

\section{Conclusion and Recommendations}

Men and women rural farmers were more diversified compared to their women counterparts. Education of male and female entrepreneurs should be encouraged and access to resources among rural farming households to stem up their creative thinking. Also, programmes that will further improve rural farmers' access to credit should be vigorously pursued and the number of agricultural extension visits should be increased. 
Creative Commons User License: CC BY-NC-ND

Abstracted by: EBSCOhost, Electronic Journals Service (EJS), Google Scholar, Journal Seek, Scientific Commons,

Food and Agricultural Organization (FAO), CABI and Scopus
Journal of Agricultural Extension

Vol. 23 (4) October, 2019

ISSN(e): 24086851; ISSN(Print); 1119944X

http://journal.aesonnigeria.org

http://www.ajol.info/index.php/jae

Email: editorinchief@aesonnigeria.org

\section{References}

Campaña, J.C., Giménez-Nadal, J.I. \& Molina, J.A. (2017): Differences between selfemployed and employed mothers in balancing family and work responsibilities: Evidence from Latin American countries. MPRA Paper 77964.

Dau I.A and Cuervo-cazurra, A (2014) To formalize or not to formalize: Entrepreneurship and pro-market institutions. J. Bus Vent 29: 668-686.

Daudu, A.K, Oladipo, F.O and Kayode, A.O (2017): Gender capacity building needs on soil fertility management practices among smallholder arable crop farmers in Kwara State, Nigeria. Journal of the Saudi Society of Agricultural Sciences. http://dx.doi.org/10.1016/issas.2017.06.003

Estruk, O.\& Oren, M. (2014). Impact of household socio-economic factors on food security: Case of Adana, Turkey. Pakistan Journal of Nutrition, 13(1), 1-6.

Dzanku, F.M and Sarpong, D.B. (2014): "Household-level farm-nonfarm linkages and household welfare implications," in AFRINT 3: Ghana Micro Report, 2014.

Global Entrepreneurship Monitor (2012): Global Report. Published online, http://www.gemconsortium.org

Idris, A. J. (2015) Effect of social capital on poverty alleviation: a study of women entrepreneurs in Nasarawa state, Nigeria. JORIND 13(1): 208-222 www.transcampus.org/journal;

Nkpoyen, F. and Bassey, G. E. (2012). Micro-lending as an empowerment strategy for poverty alleviation among women in Yala Local Govt. Area of Cross River State, Nigeria. International Journal of Business and Social Science, 32(18), 233- 241.

Nwala, M. N. and Alfred (2013) Financing and related constraints to the growth of women entrepreneurship: Evidence from Nasarawa State, Nigeria. Archives of Applied Science Research, 5(6): 165-171.

http://scholarsresearchlibrary.com/archive.html

Nwibo, S. U. and Okorie, A. (2013) Constraints to entrepreneurship and investment decisions among agribusiness investors in southeast, Nigeria. International Journal of Small Business and Entrepreneurship Research, 1(4): 38-50.

Ogundele, J.J.K., Akingbade, W.A \& Akinlabi, H.B. (2012). Entrepreneurship training and education as strategic tools for poverty alleviation in Nigeria. American International Journal of Contemporary Research, 2(1): 148-156.

Quisumbing, A. R., R. Meinzen-Dick, T. L. Raney, A. Croppenstedt, J. A. Behrman, and A. Peterman (2014). 'Closing the knowledge gap on gender in agriculture.' In Gender in agriculture. Dordrecht, Springer.

Sadiya, S.I and Man, N (2012): "Off-farm employment participation among paddy 
Creative Commons User License: CC BY-NC-ND

Abstracted by: EBSCOhost, Electronic Journals Service (EJS),

Google Scholar, Journal Seek, Scientific Commons,

Food and Agricultural Organization (FAO), CABI and Scopus

http://eoi.citefactor.org/10.11226/v23i4
Journal of Agricultural Extension

Vol. 23 (4) October, 2019

ISSN(e): 24086851; ISSN(Print); 1119944X

http://journal.aesonnigeria.org

http://www.ajol.info/index.php/jae

Email: editorinchief@aesonnigeria.org

faremers in the muda agricultural development authority and kemasin semerak granary areas of Malaysia," Asia-Pacific Development Journal, vol. 16, no. 2, pp. 141-153.

Umeh, O.J. (2016). Factor influencing extension services delivery and performance of Abia State Agricultural Development Programmes (ADP). International Journal of Applied Research and technology. 5(8): $10-15$.

United Nation Development Programme (2013): Human Development Report 2013. The Rise of the South: Human Progress in a Diverse World. New York: UNDP 